\title{
Iron chelation studies using desferrioxamine and the potential oral chelator, 1,2-dimethyl-3-hydroxypyrid-4-one, in normal and iron loaded rats
}

\author{
G J KONTOGHIORGHES, * L SHEPPARD, * A V HOFFBRAND,* \\ J CHARALAMBOUS, $\dagger$ J TIKERPAE, $\ddagger$ M J PIPPARD $\ddagger$
}

From the *Department of Haematology, Royal Free Hospital School of Medicine, London, the $\dagger$ School of Chemistry, The Polytechnic of North London, and the $\ddagger$ Section of Haematology, Medical Research Council Clinical Research Centre, Northwick Park Hospital, Harrow, Middlesex

SUMMARY A novel iron chelator, 1,2-dimethyl-3-hydroxypyrid-4-one, and desferrioxamine were compared for their ability to remove iron and for their site of action in iron release in rats. Repeated intraperitoneal injections of the chelators in rats with widespread tissue labelling by ${ }^{59} \mathrm{Fe}$ derived from transferrin showed comparable ${ }^{59} \mathrm{Fe}$ mobilisation by each chelator in normal and iron loaded rats. Specific labelling of a chelatable "cold" iron pool in hepatocytes by ${ }^{59} \mathrm{Fe}$ derived from ferritin showed this pool to be equally accessible to parenteral doses of both chelators and also to oral 1,2-dimethyl-3-hydroxypyrid-4-one, which is an effective oral iron chelating agent that removes iron from parenchymal cells. This and other $\alpha$-ketohydroxypyridines need further development as potential therapeutic agents in human iron overload.

The treatment of iron overload in transfusion dependent thalassaemia using desferrioxamine is expensive $^{1}$ and hence unobtainable in most parts of the world where the disease is common. Furthermore, the need to administer desferrioxamine by continuous subcutaneous infusion often leads to poor compliance with the treatment. ${ }^{2}$ Consequently, there is a need for a new, cheap, orally active, non-toxic iron chelator. The $\alpha$-ketohydroxypyridines ${ }^{3}$ are a promising group of iron chelators which have been shown to remove iron from transferrin, ${ }^{4}$ and ferritin ${ }^{5}$ in vitro, and from mice $^{67}$ and rabbits, ${ }^{8}$ when administered orally and parenterally.

Our studies compared the iron chelating ability of desferrioxamine and 1,2-dimethyl-3-hydroxypyrid4-one $\left(L_{1}\right)$ in rats, being particularly concerned with determining the effect of repeated parenteral doses of the drugs in normal and iron loaded animals; the main site of action of the drugs; and the relative efficiency of oral and parenteral doses of $L_{1}$. To follow iron mobilisation by the drugs two different tech-

Accepted for publication 13 November 1986 niques for labelling the rats with ${ }^{59} \mathrm{Fe}$ were used: in the first, injection of ${ }^{59} \mathrm{Fe}$-labelled transferrin distributed radioiron throught the body, most particularly in the red cells and liver; and in the second, ${ }^{59} \mathrm{Fe}$-labelled ferritin was used to label specifically a pool of metabolically active chelatable iron within rat liver parenchymal cells. ${ }^{910}$

\section{Material and methods}

$\mathrm{L}_{1}$ was prepared according to the method of Kontoghiorghes. ${ }^{3}$ Desferrioxamine was obtained from Ciba-Geigy, Horsham, Sussex; phosphate buffered saline from Oxoid, Basingstoke; iron dextran (Imferon) from Fisons, Loughborough; human transferrin from Sigma, and ${ }^{59} \mathrm{Fe}$ citrate from Amersham International. Male Sprague Dawley rats were used for the ${ }^{59} \mathrm{Fe}$ transferrin and female Sprague Dawley rats for the ${ }^{59} \mathrm{Fe}$ ferritin studies. All the rats were fed with grain harvested $41 \mathrm{~B}$ pellets.

PREPARATION OF ${ }^{59} \mathrm{Fe}-\mathrm{TR}$ ANSFERRIN AND
${ }^{59} \mathrm{Fe}-\mathrm{FERRITIN}$
${ }^{59} \mathrm{Fe}$ citrate $(62.5 \mu \mathrm{Ci}, 5.65 \mu \mathrm{g} \mathrm{Fe}, 625 \mu \mathrm{l})$ was first
added to apotransferrin $(75 \mathrm{mg}$ in $2 \mathrm{ml}$ phosphate 
buffered saline). After 30 minutes of incubation aqueous ferrous ammonium sulphate $(1 \mathrm{ml}, 96 \mu \mathrm{g} \mathrm{Fe})$ and double strength phosphate buffered saline $(1 \mathrm{ml})$ were added stepwise at five minute intervals before making a total volume of $12.5 \mathrm{ml}$ with phosphate buffered saline. The resulting pink ${ }^{59} \mathrm{Fe}$ transferrin solution was incubated for a further two hours before being given intravenously to rats.

Rat liver ferritin was labelled with ${ }^{59} \mathrm{Fe}$ in vivo. It was isolated from the heat supernatant of a liver homogenate prepared in $0.25 \mathrm{M}$ acetate buffer $(\mathrm{pH}$ $4 \cdot 8)$ and purified by ultracentrifugation. ${ }^{11}$

\section{STUDIES USING ${ }^{59} \mathrm{Fe}-\mathrm{TRANSFERRIN}$}

Nine rats were given intraperitoneal injections of iron dextran every three days over two weeks, amounting to a total of $140 \mathrm{mg}$ iron for each rat. Five weeks after the last injection the nine iron loaded and 14 normal rats were labelled with ${ }^{59} \mathrm{Fe}$ by injecting ${ }^{59} \mathrm{Fe}$ transferrin $(2 \mu \mathrm{Ci}, 400 \mu \mathrm{l})$ via the tail vein, and divided into five cages (three of normal and two of iron loaded rats). Subsequent total ${ }^{59} \mathrm{Fe}$ excretion (urine plus faeces) in eight separate weekly collections of the cage litter, and the radioactivity remaining in each group of rats at the end of the studies, were measured in a large volume gamma counter. About $200 \mathrm{mg} / \mathrm{kg}$ of chelators were given by daily intraperitoneal injection during the third and sixth weeks after ${ }^{59} \mathrm{Fe}$-transferrin labelling. One control group received no chelator injections.

STUDIES USING ${ }^{59} \mathrm{Fe}$-LABELLED FERRITIN ${ }^{59} \mathrm{Fe}$-ferritin iron $(7.5 \mu \mathrm{g}$ iron, $0.2 \mu \mathrm{Ci})$ was injected intravenously via the lateral tail vein two hours before the test chelator was given. Food was removed from the test rats (weight 180-220 g) during the night before each experiment, although free access to water was permitted. After administration of the chelator rats were placed in metabolic cages for collection of urine and faeces during the subsequent four hours, after which the animals were killed. ${ }^{11}$

In some studies bile cannulation was carried out under Hypnorm (Fentanyl citrate, $0.315 \mathrm{mg} / \mathrm{ml}$ : Fluanisone, $10 \mathrm{mg} / \mathrm{ml}$, Crown Chemicals, Lamberhurst, Kent) and diazepam anaesthesia. PE50 tubing was inserted into the bile duct above the pancreas. During collection of bile the anaesthesia was repeated as necessary, and fluid replacement equal to the bile drain ( $1 \mathrm{ml} /$ hour) was given by subcutaneous injection of saline. The intravenous injection of ${ }^{59} \mathrm{Fe}$-ferritin was given immediately after completion of the operation, followed at two hours by administration of the chelator.

The rats were killed at six hours by exsanguination from the abdominal aorta followed by perfusion with $20 \mathrm{ml}$ of physiological saline before removal of the organs for ${ }^{59} \mathrm{Fe}$ counting. Radioactivity in the liver, gut and contents, or bile, faeces, blood, residual carcass and urine was determined using an automatic well gamma counter. Tails and residual carcasses were counted separately in a large volume counter with corrections for differences in geometry. The percentage of the total injected counts in each organ was standardised to a total recovery of $100 \%$. Urine and bile iron content was measured colorimetrically using bathophenanthroline sulphonate. Liver non-haem iron was determined in homogenates of the liver using a modification of the hydrochloric acid method of Kaldor. ${ }^{12}$

Iron chelators were prepared in aqueous solution to give a final dose of $40 \mathrm{mg}$ in $0.5 \mathrm{ml}$. Intramuscular doses were given into the hind limb and oral doses were given using a stomach tube.

\section{Results}

STUDIES USING ${ }^{59} \mathrm{Fe}-L A B E L L E D$ TRANSFERRIN After the administration of ${ }^{59} \mathrm{Fe}$-transferrin ${ }^{59} \mathrm{Fe}$ excretion in control rats was maximal in the first two weeks (fig 1). It then remained relatively stable, declining only slowly over the rest of the study period.

In normal rats administration of intraperitoneal $L_{1}$ (fig 1) or desferrioxamine (fig 1) caused a substantial increase in the overall ${ }^{59} \mathrm{Fe}$ excretion. ${ }^{59} \mathrm{Fe}$ excretion was higher in the third week than the sixth week. In iron loaded rats treated with $L_{1}$ (fig 1) and desferrioxamine (fig 1) the ${ }^{59} \mathrm{Fe}$ excretion was similar in amount and profile to that seen in the normal animals. Most of the ${ }^{59} \mathrm{Fe}$ remained in the rats even after prolonged chelation (table 1). Weight gain was not affected by chelator treatment and all the rats were alive seven months later. Within minutes of injection, however, $\mathrm{L}_{1}$ produced hypersalivation, which continued for one to two hours. This was also seen after oral and intramuscular injection of $L_{1}$ in the ${ }^{59} \mathrm{Fe}$-ferritin study, in contrast to the injections of desferrioxamine which had no obvious adverse effects. In a preliminary study the administration of $\mathrm{L}_{1}$ to normal rats under anaesthetic (Hypnorm) did not cause any salivation.

STUDIES USING ${ }^{59}$ Fe-FERRITIN

When control rats were killed six hours after intravenous ${ }^{59} \mathrm{Fe}$-ferritin injection, over $90 \%$ of the ${ }^{59} \mathrm{Fe}$ remained in the liver (fig 2). With desferrioxamine or $\mathrm{L}_{1}$ given two hours after the ${ }^{59} \mathrm{Fe}$ injection, about $40 \%$ of the ${ }^{59} \mathrm{Fe}$ was mobilised from the liver into the gut (fig 2). Oral and intramuscular $L_{1}$ were of comparable efficiency.

The ${ }^{59} \mathrm{Fe}$ appearing in the gut was derived from biliary excretion (table 2). Carrier iron excretion in 

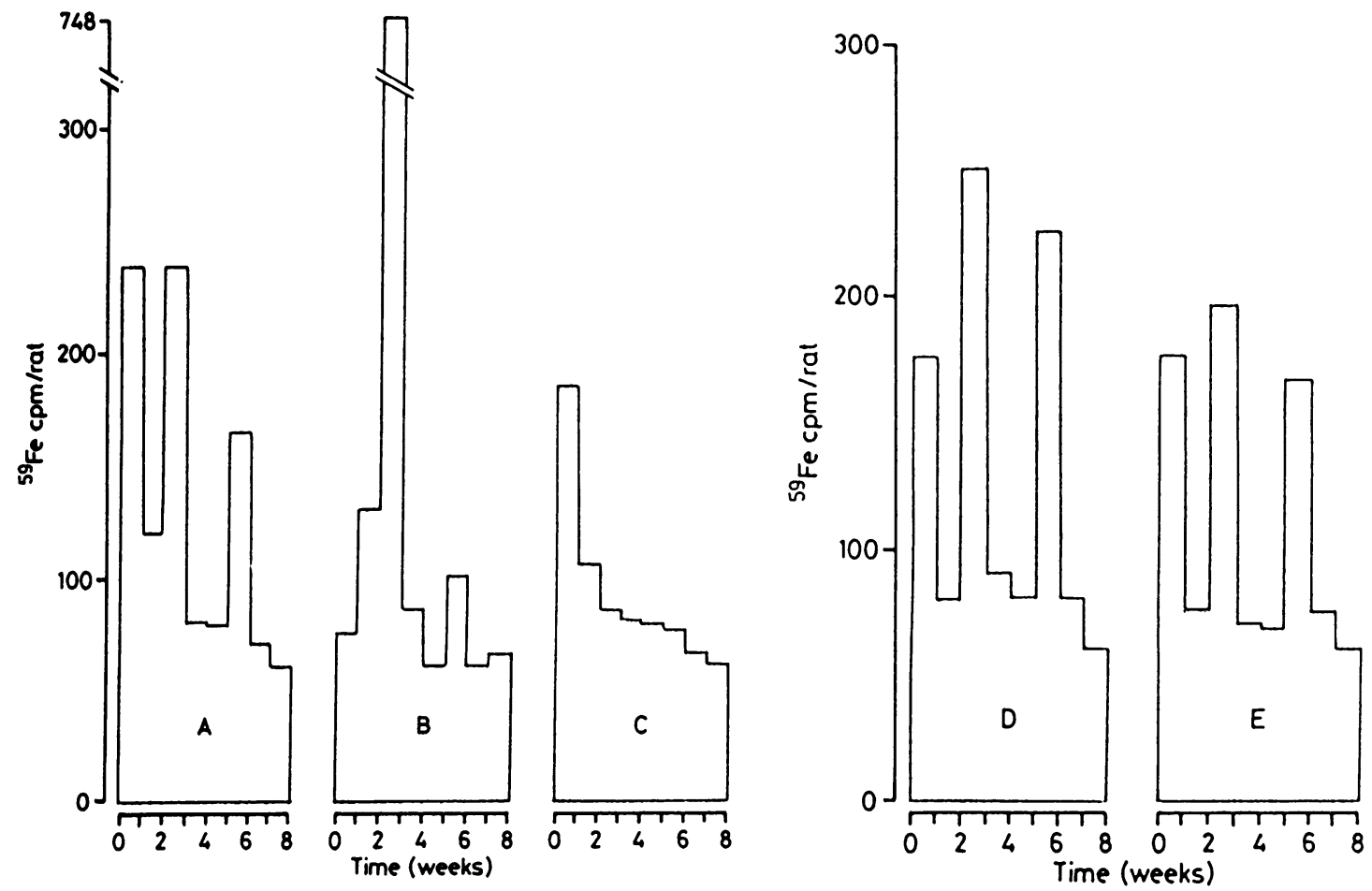

Fig 1 Weekly ${ }^{59} \mathrm{Fe}$ excretion profiles in groups of normal $(A, B, C)$ and iron loaded $(D, E){ }^{59} \mathrm{Fe}$ transferrin. Intraperitoneal injections of $L_{1}$ (groups $A, D$ ) or desferrioxamine (groups $B, E$ ) were given during weeks 3 and 6 at a dose of about $200 \mathrm{mg} / \mathrm{kg} /$ day. Group C received no chelator injections.

the bile was also greatly increased with both chelators, and only small amounts of iron were mobilised into the urine. There was no additive effect when combined intramuscular injections of $40 \mathrm{mg}$ of desferrioxamine and $L_{1}$ were given. In addition, the inverse relation between the dilution of the ${ }^{59} \mathrm{Fe}$ by cold iron in the bile (bile specific activity) and the total liver non-haem iron content was similar with each chelator and with their combination (fig 3).

\section{Discussion}

These studies have shown that in both models desferrioxamine and $L_{1}$ produce comparable chelation of iron. In the rats allowed to reach a steady state of ${ }^{59} \mathrm{Fe}$ excretion after labelling with ${ }^{59} \mathrm{Fe}$-transferrin, however, the absolute amounts of ${ }^{59} \mathrm{Fe}$ mobilised were small, despite repeated injections (table 1). In addition, iron loading with iron dextran (initially cleared to macrophages) had little effect on the amount of ${ }^{59} \mathrm{Fe}$ excreted, suggesting that the chelata- ble ${ }^{59} \mathrm{Fe}$ was largely independent of or non-diluted by this iron dextran storage pool. In contrast, large amounts of ${ }^{59} \mathrm{Fe}$ were available to both $L_{1}$ and desferrioxamine using the ${ }^{59} \mathrm{Fe}$ ferritin model, where the ${ }^{59} \mathrm{Fe}$ is released transiently within a chelatable pool within hepatocytes. ${ }^{11}$ Oral and parenteral doses of $\mathrm{L}_{1}$ were comparable to desferrioxamine in their efficiency of mobilising ${ }^{59} \mathrm{Fe}$ (fig 2). In both cases most of the ${ }^{59} \mathrm{Fe}$ was excreted in the bile. The lack of any additive effect with the two drugs at the dose used and the similar relation between bile ${ }^{59} \mathrm{Fe}$ and carrier iron with both chelators (fig 3 ) suggest that the drugs chelated iron from the same site within hepatocytes. Like desferrioxamine, $L_{1}$ therefore seems to be able to penetrate the liver parenchymal cells which are a major site of iron storage in human primary or secondary haemochromatosis.

During the present studies, no deaths or evidence of failure to thrive (table 1) were observed in either normal or iron loaded animals. Pronounced salivation was observed with either parenteral or oral adminis- 


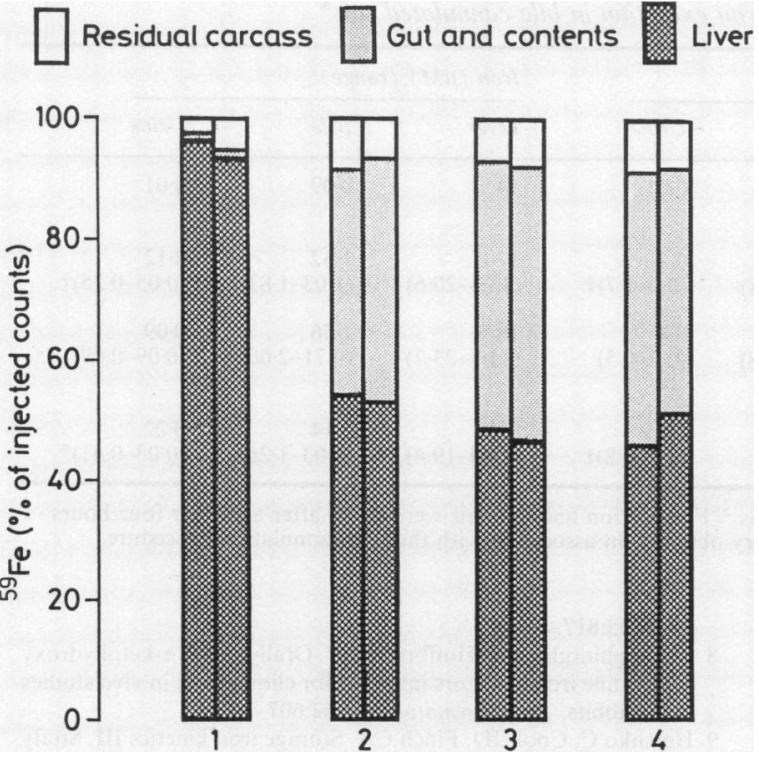

Fig 2 Distribution of ${ }^{59} \mathrm{Fe}$ six hours after intravenous administration of ${ }^{59} \mathrm{Fe}$-ferritin. Iron chelators were given after two hours (1: control, no chelator; 2: desferrioxamine $40 \mathrm{mg}$ intramuscularly; $3: L_{1} 40 \mathrm{mg}$ intramuscularly; $4: L_{1}$ $40 \mathrm{mg}$ orally). Each column represents one rat. Urine ${ }^{59} \mathrm{Fe}$ was less than $0.5 \%$ in all cases.

tration of $\mathrm{L}_{1}$, however, an effect which was not seen in mice $^{67}$ and rabbits. ${ }^{8}$ It remains to be determined whether this adverse effect is related to the bitter taste of the drug and also whether other $\alpha$-ketohydroxypyridine analogues ${ }^{613}$ of $L_{1}$ may have the same effect. Nevertheless, the present demonstration that in the rat $L_{1}$ is of equal efficiency to desferrioxamine during a long term treatment and also that it acts as a parenchymal iron chelating agent, which has the additional advantage of oral

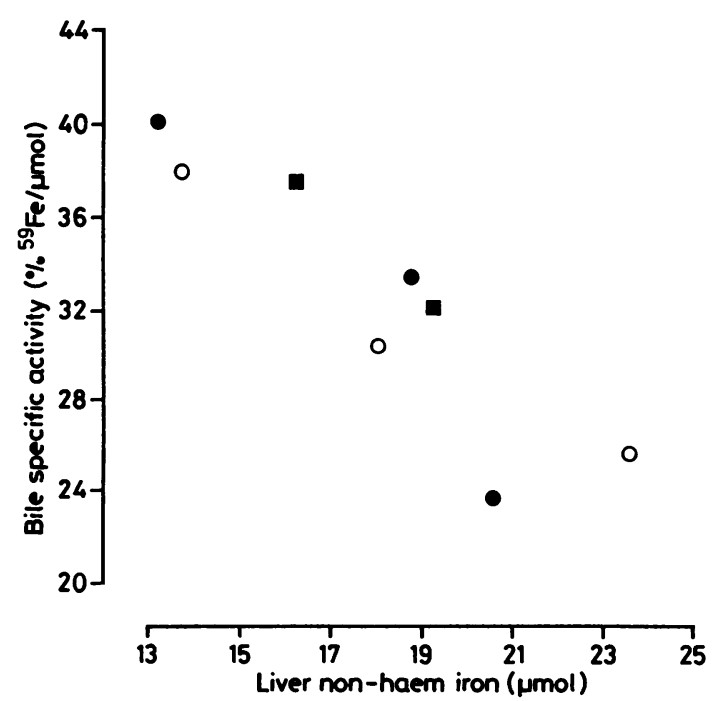

Fig 3 Relation between bile specific activity (per cent injected ${ }^{59} \mathrm{Fe}$ in bile divided by $\mu \mathrm{M}$ iron in bile) and liver non-haem iron content. Each point represents results from one rat (- desferrioxamine $40 \mathrm{mg}$ intramuscularly; $\bigcirc L_{1}$ $40 \mathrm{mg}$ intramuscularly; desferrioxamine $40 \mathrm{mg}$ intramuscularly plus $L_{1} 40 \mathrm{mg}$ intramuscularly).

activity, should stimulate the further investigation into the development of $L_{1}$ or its analogues ${ }^{13}$ as potential agents for the treatment of iron overload in human disease.

This work was supported by the United Kingdom Thalassaemia Society. We thank S Chambers, and A Dodd for their technical assistance, DP Moore and AJ Palmer for helping in the animal studies, and Mrs J Wilkinson for word processing.

Table 1 Effect of chelators on growth and ${ }^{59} \mathrm{Fe}$ content of ${ }^{59} \mathrm{Fe}$-transferrin labelled rats

\begin{tabular}{|c|c|c|c|c|c|c|c|c|}
\hline \multirow[b]{2}{*}{ Group } & \multirow[b]{2}{*}{$(n=)$} & \multirow[b]{2}{*}{ Chelator } & \multirow{2}{*}{$\begin{array}{l}\text { Dose (in } \\
\text { weeks } 3,6) \\
\text { (mg/day/rat) }\end{array}$} & \multicolumn{2}{|c|}{$\begin{array}{l}\text { Rat weights }(\mathrm{g}) \\
\text { before study }\end{array}$} & \multicolumn{2}{|c|}{$\begin{array}{l}\text { Rat weights }(\mathrm{g}) \\
\text { after study }\end{array}$} & \multirow{2}{*}{$\begin{array}{l}\text { Rat }{ }^{59} \mathrm{Fe} \text { content } \\
\text { (cpm) after } \\
\text { study }\end{array}$} \\
\hline & & & & Mean & Range & Mean & Range & \\
\hline $\begin{array}{l}\text { Normal rats: } \\
\text { A } \\
\text { B } \\
\mathbf{C}\end{array}$ & $\begin{array}{l}5 \\
5 \\
4\end{array}$ & $\begin{array}{l}\mathrm{L}_{1} \\
\text { Desferrioxamine }\end{array}$ & $\begin{array}{l}40^{*} \\
40^{*}\end{array}$ & $\begin{array}{l}220 \\
220 \\
436\end{array}$ & $\begin{array}{l}(180-240) \\
(180-240) \\
(400-500)\end{array}$ & $\begin{array}{l}448 \\
466 \\
619\end{array}$ & $\begin{array}{l}(400-518) \\
(431-502) \\
(610-635)\end{array}$ & $\begin{array}{l}30802 \\
28110 \\
30941\end{array}$ \\
\hline $\begin{array}{l}\text { Iron loaded rats: } \\
\mathrm{D}\end{array}$ & $\begin{array}{l}5 \\
4\end{array}$ & $\begin{array}{l}\mathrm{L}_{1} \\
\text { Desferrioxamine }\end{array}$ & $\begin{array}{l}80 \dagger \\
80 \dagger\end{array}$ & $\begin{array}{l}412 \\
412\end{array}$ & $\begin{array}{l}(350-460) \\
(350-460)\end{array}$ & $\begin{array}{l}546 \\
508\end{array}$ & $\begin{array}{l}(504-595) \\
(459-615)\end{array}$ & $\begin{array}{l}31864 \\
32656\end{array}$ \\
\hline
\end{tabular}

*Group A received $5 \times 40 \mathrm{mg}$ doses and $1 \times 20 \mathrm{mg}$ dose in week 3 and $6 \times 40 \mathrm{mg}$ doses in week 6; group B received $7 \times 40 \mathrm{mg}$ doses in both weeks 3 and 6.

† Group D received $5 \times 80 \mathrm{mg}$ doses and $1 \times 40 \mathrm{mg}$ dose in week 3 and $6 \times 80 \mathrm{mg}$ doses in week 6; group E received $7 \times 80 \mathrm{mg}$ doses in both weeks 3 and 6. 
Table 2 Distribution of ${ }^{59} \mathrm{Fe}$ derived from ferritin and cold iron excretion in bile cannulated rats*

\begin{tabular}{|c|c|c|c|c|c|c|c|}
\hline \multirow[b]{2}{*}{ Chelator } & \multirow[b]{2}{*}{$(n=)$} & \multicolumn{3}{|c|}{$\%{ }^{59} \mathrm{Fe}$ (range) } & \multicolumn{3}{|c|}{ Iron $(\mu M)$ (range) } \\
\hline & & Liver & Bile & Urine & Liver & Blle & Urine \\
\hline Control & 1 & $90 \cdot 2$ & 0.70 & 0.01 & $14 \cdot 7$ & 0.09 & 0.01 \\
\hline $\begin{array}{l}\text { Desferrioxamine } \\
\text { intramuscularly }\end{array}$ & 3 & $\begin{array}{l}43 \cdot 9 \\
(36 \cdot 1-50 \cdot 3)\end{array}$ & $\begin{array}{l}47 \cdot 2 \\
(41 \cdot 2-56 \cdot 8)\end{array}$ & $\begin{array}{l}0 \cdot 8 \\
(0 \cdot 2-1 \cdot 7) \dagger\end{array}$ & $\begin{array}{l}17 \cdot 6 \\
(13 \cdot 3-20 \cdot 6)\end{array}$ & $\begin{array}{l}1.52 \\
(1.03-1.83)\end{array}$ & $\begin{array}{l}0.12 \\
(0.05-0.25) \dagger\end{array}$ \\
\hline $\mathrm{L}_{1}$ intramuscularly & 3 & $\begin{array}{l}45 \cdot 6 \\
(32 \cdot 2-61 \cdot 2)\end{array}$ & $\begin{array}{l}46 \cdot 2 \\
(27 \cdot 3-60 \cdot 8)\end{array}$ & $\begin{array}{l}0 \cdot 4 \\
(0 \cdot 2-0 \cdot 5)\end{array}$ & $\begin{array}{l}18 \cdot 5 \\
(13 \cdot 8-23 \cdot 7)\end{array}$ & $\begin{array}{l}1 \cdot 56 \\
(0 \cdot 71-2 \cdot 00)\end{array}$ & $\begin{array}{l}0.09 \\
(0.09-0.09)\end{array}$ \\
\hline $\begin{array}{l}\text { Desferrioxamine } \\
\text { intramuscularly } \\
\quad+L_{1} \text { intramuscularly }\end{array}$ & 2 & $\begin{array}{l}48 \cdot 5 \\
(37 \cdot 0-60 \cdot 0)\end{array}$ & $\begin{array}{l}40 \cdot 2 \\
(33-47 \cdot 4)\end{array}$ & $\begin{array}{l}2 \cdot 45 \\
(0 \cdot 1-4 \cdot 8) \dagger\end{array}$ & $\begin{array}{l}17 \cdot 9 \\
(16 \cdot 4-19 \cdot 4)\end{array}$ & $\begin{array}{l}1 \cdot 14 \\
(1 \cdot 03-1 \cdot 26)\end{array}$ & $\begin{array}{l}0.22 \\
(0.03-0.41) \dagger\end{array}$ \\
\hline
\end{tabular}

${ }^{*}$ Chelators were given at a dose of $40 \mathrm{mg}$ two hours after intravenous ${ }^{59} \mathrm{Fe}$ injection and animals were killed after a further four hours. +Wide variation in urine values is due to the effects of transient biliary obstruction associated with the bile cannulation procedure.

\section{References}

1 Brown EG. Thalassaemia. In: Brewer GJ, ed. Orphan drugs and orphan diseases. Clinical realities and public policy. New York: Alan R Liss 1983:33-42.

2 Wolfe L. Prevention of cardiac disease by subcutaneous deferoxamine in patients with thalassaemia major. $N$ Engl $J$ Med 1985;312:1600-3.

3 Kontoghiorhes GJ. The design of orally active iron chelators for the treatment of thalassaemia. Essex, University of Essex, 1982. (Thesis.)

4 Kontoghiorghes GJ. The study of iron mobilisation from transferrin using $\alpha$-ketohydroxy heteroaromatic chelators. Biochim Biophys Acta 1986;869:141-6.

5 Kontoghiorghes GJ. Iron mobilisation from ferritin using $\alpha$-oxohydroxy heteroaromatic chelators. Biochem $J$ 1986;233:299-302.

6 Kontoghiorghes GJ. Dose response studies using desferrioxamine and orally active chelators in a mouse model. Scand J Haematol 1986;37:63-70.

7 Kontoghiorghes GJ. New orally active iron chelators. Lancet
$1985 ; \mathbf{i}: 817$.

8 Kontoghiorghes GJ, Hoffbrand AV. Orally active $\alpha$-ketohydroxy pyridine iron chelators intended for clinical use: in vivo studies in rabbits. Br J Haematol 1986;62:607-13.

9 Hershko C, Cook JD, Finch CA. Storage iron kinetics III. Study of desferrioxamine action by selective radio-iron labels of RE and parenchymal cells. J Lab Clin Med 1973;81:876-8.

10 Pippard MJ, Johnson DJ, Finch CA. Hepatocyte iron kinetics in the rat, explored with an iron chelator. Br J Haematol 1982;52:211-24.

11 Pippard MJ, Johnson DK, Finch CA. A rapid assay for evaluation of iron chelating agents in rats. Blood 1981;58:685-92.

$12 \mathrm{Kaldor}$ I. Studies on intermediary iron metabolism V. The measurement of non-haemoglobin tissue iron. Aust J Exp Biol Med Sci 1954;32:795-800.

13 Kontoghiorghes GJ. Orally active $\alpha$-ketohydroxypyridine iron chelators: studies in mice. Mol Pharmacol 1986;30:670-3.

Requests for reprints to: Dr G J Kontoghiorghes, Department of Haematology, Royal Free Hospital School of Medicine, Hampstead, London NW3 2QG, England. 